\title{
EXPLORING THE MOTIVATION OF STUDENTS IN CHOOSING INFORMATION SYSTEMS AS THEIR MAJOR
}

\author{
Roman M. Wong, Barry University, rwong@mail.barry.edu \\ Anne M. Fiedler, Barry University, afiedler@mail.barry.edu \\ Che-Hung Liu, Florida International University, cliu001@fiu.edu
}

\begin{abstract}
As part of the effort to investigate what motivates(or de-motivates) a student to choose information systems as his/her major of study, this paper looks into the differences in terms of career outcomes as the students perceived in each of the five functional majors in the business schools. It also discusses how the students' perceived career outcomes of choosing an IS major are different from their personal preference. The career outcomes are defined in terms of Schein's [1] and DeLong's [2] Career Anchors. Our discussions are based on the empirical data collected from 106 business students in two universities located in a southeastern state.
\end{abstract}

Keywords: Career anchors, choice of majors information systems majors, motivating factors

\section{INTRODUCTION}

The number of positions for computer and information systems managers is expected to grow at a rate that is faster than the average for all occupations through the year 2014 [3]. This is because technological advancements are expected to boost the employment of computer-related workers; as a result, the demand for managers to direct these workers also will increase. According to the Bureau of Labor Statistics, these positions will be open to those with computer-related work experience, an MBA with technology as a core component, or a management information systems degree.

Despite this positive trend in the job market, IS departments in the United States have still experienced 25 to 75 percent enrollment reduction in recent years [4]. According to the Taulbee Survey from the Computing Research Association [5], the enrollments in computer science related majors dropped 14 percent between 2004/2005 and 2005/2006 with an overall drop in enrollment of 39 percent from their height in 2001/2002.

Several papers have begun to exam why students choose different majors based on such factors as gender, personality, and quantitative ability. In an attempt to understand why students are becoming less and less motivated to choose computer related majors despite the positive outlook suggested by the BLS, this exploratory study will take this body of knowledge a step further by comparing the outcomes that are important to the students in their future career with those that they believe to be attainable by completing an IS major compared to other functional business majors. In this effort, we used Career Anchors as a format to measure the reward outcomes that students seek in their careers. We also examined how students perceive the relationship of these career outcomes to the various majors. This will give us the first clue in attempting to solve the puzzle as to why these students are failing to see these majors as viable paths that will lead to the outcomes that they are seeking.

\section{PRIOR STUDY}

\section{Choice of Business Majors}

There have been numerous studies investigating factors influencing why students choose college majors, in general, and business major, in specific. Some of the studies looked at the influence of demographics factors such as gender, race, and ethnic origin [6-8]. For example, Malgwi, Howe, and Burnaby [9] found that for women the choice of major was influenced by aptitude in the subject. However, men were significantly more influenced by the major's potential for career advancement, job opportunities, and the level of compensation in the field.

Other studies examined factors such as personality traits, quantitative abilities, and marketability when choosing a major. Noel, Michaels, and Levas [10] found that personality stereotyping and related self-monitoring behaviors take place in students' selection of a business major. For example, accounting majors were significantly more reserved, prone to use concrete and focused thinking, affected by feelings, restrained, persistent, timid, practical, and tense in their personal interactions. MIS majors as well marketing majors were more likely to control the impressions that they made on others, portray a deliberate image, adjust their behavior to a situation, emotionally read others, spot liars, or tell whether 
others considered a joke in poor taste than accounting majors. Also, accounting students reflecting more concentrated thinking rather than the more creative and abstract thinking more commonly found among MIS and marketing students.

Pritchard, Potter, and Saccucci [11] looked at quantitative skills as a precondition to major selection. They found that whereas those with better quantitative skills tended to major in accounting or finance, those with weaker quantitative skills tended to major in MIS, marketing and management. However, since the sample only contained four MIS majors, the authors concluded that findings regarding this major were inconclusive.

A study on why student do not choose economics as a major [12] found that interest in the subject, expected marketability, performance in major classes, and the approachability and teaching reputation of the faculty are impacted the choice of major.

\section{Choice of Information Systems as Major}

The decrease in the number of students choosing to major in information systems (IS) and computer related fields has encouraged researchers to investigate factors influencing the choice of the IS major in particular. Moody, Woszczynski, Beise and Myers [13] examined the opportunities and barriers for women seeking careers in IS. A more recent study [14] looked at the students' perceptions of IS work based on various demographic variables such as gender, ethnicity, age, and disability status. The authors found no significant differences based on gender, age, work experience, and disability status; however, they did find significant differences in perceptions based on ethnicity, as well as differences based on college major.

\section{CAREER ANCHORS}

The face of business is changing at a rapid pace. As a result positions in corporations as well as career paths are constantly evolving. As corporations are reengineering, downsizing, rightsizing, and outsourcing employees must adjust their career expectations continually. Schein [1] suggests that the "organizational career," which consists of formal stages and roles defined by organizational policies and societal concepts of what an individual can expect in the occupational structure, will be replaced by an "internal career" involving a subjective sense of where one is going in one's work life.

Schein $[1,2]$ referred to this strong self-concept of an employee's internal career as a "career anchor." He originally found that employees' anchored their careers around five categories reflecting basic values, motives, and needs: 1) Autonomy/independence; 2) Security/stability; 3) Technical-functional competence; 4) General Managerial Competence; and 5) Entrepreneurial Creativity. However, after further study he revised his list of career anchors to include three additional anchor categories; 6) Service or Dedication to a Cause; 7) Pure Challenge; and 8) Life Style. Schein believed that most people have one of these eight categories as an anchor, the thing they will not give up, but most careers also permit the fulfilling of several of the needs that underlie different anchors.

DeLong [2] conducted further testing Schein's model. While his findings generally supported the anchors introduced by Schein, he found that the security anchor should actually be split into two separate anchors (organizational security and geographic security, thus resulting in nine career anchors.

\section{METHOD OF STUDY}

The survey instrument was given to undergraduate business students at one private and one public university. The survey consisted of 24 statements patterned after those used in the career anchor study by DeLong [2]. To measure the outcomes that the students would seek in a career, the students were asked to rate each of the career anchor statements based on the question, "How appealing is each of the following to you in considering a career?" In the second section of the instrument, students were asked to rate each of the career anchor statements based on how likely each of the five functional majors (accounting, finance, IS, marketing, and management) would provide that career outcome. Thus, in the second section, the students evaluate each of the five majors on each of the 24 outcome statements.

The surveys were completed by 106 students including 26 sophomores, 56 juniors, 17 seniors, and one graduate student. Forty-seven percent (48) of the respondents were women and 53\% (54) were men. The average age of the students surveyed was 22.6 years. 


\section{DATA ANALYSIS}

\section{Factor Analysis}

Our objective for conducting a factor analysis was to confirm that the structure of the common dimensions underlying the twenty-four items of the Career Anchors inventory was in compliant with the Career Anchors of Schein and DeLong. The extraction method used in this study was the principal components method. Factors were extracted with an Eigen value of over one. The factors were rotated using the Varimax method, which is an orthogonal rotational method. In interpreting the factor matrix, we identified the highest loading for each of the 24 items on the factors; we then retained only those items that contributed at least $60 \%$ of the variance for the respective factor.

As a result eight factors were retained. Based on the interpretation of their representative items, we concluded that the following dimensions were obtained:

1. Technical and functional competency

2. General management competency

3. Autonomy/Independency and Life Style

4. Security and Stability

5. Geographic Security

6. Entrepreneurial Creativity

7. Service and Dedication to a Cause

8. Pure Challenge

The factor structure derived from the 24-item Career Anchor inventory substantially conforms to that of Schein and DeLong. The difference is that, to the subjects in this study, the dimension of independency and life style are not distinctive enough to be perceived as two separate ones. The factor structure obtained in this analysis was used to calculate each subject's rating on the factors based on their responses in the survey. The items retained for each of the factors are illustrated in Table 1.
Table 1 The eight career reward factors and their representative items

\begin{tabular}{|c|c|}
\hline Factors & Items \\
\hline Tech. Comp. & $\begin{array}{l}\text { To become highly specialized and highly } \\
\text { competent in a specific functional or } \\
\text { technical area } \\
\text { - To remain in a specialized area, as } \\
\text { opposed to being promoted out of my } \\
\text { area of expertise } \\
\text { - To remain in an area of expertise, rather } \\
\text { than being promoted into general } \\
\text { management }\end{array}$ \\
\hline Gen. Mgt. & $\begin{array}{l}\text { To supervise, influence, lead, and control } \\
\text { people at all levels } \\
\text { - To be in a position in general } \\
\text { management } \\
\text { - To rise to a position in general } \\
\text { management }\end{array}$ \\
\hline $\begin{array}{l}\text { Indep. \& Life } \\
\text { Style }\end{array}$ & $\begin{array}{l}\text { - To pursue my own lifestyle without being } \\
\text { constrained by too many rules of an } \\
\text { organization } \\
\text { - To be free from organizational } \\
\text { restrictions } \\
\text { - To enjoy a maximum of freedom and } \\
\text { autonomy to choose my own work, hours, } \\
\text { etc. } \\
\text { - To have a great deal of flexibility in the } \\
\text { job }\end{array}$ \\
\hline $\begin{array}{l}\text { Sec. \& } \\
\text { Stability }\end{array}$ & $\begin{array}{l}\text { - To obtain security through guaranteed } \\
\text { work benefits, a good retirement program, } \\
\text { etc. } \\
\text { - To obtain long-run stability }\end{array}$ \\
\hline Geo. Sec. & $\begin{array}{l}\text { To remain in my present geographical } \\
\text { location, rather than moving because of a } \\
\text { promotion }\end{array}$ \\
\hline $\begin{array}{l}\text { Ent. } \\
\text { Creativity }\end{array}$ & $\begin{array}{l}\text { - To create or build something that is } \\
\text { entirely my own product } \\
\text { - To learn skills and use those skills in } \\
\text { building my own business enterprise }\end{array}$ \\
\hline Service & $\begin{array}{l}\text { To apply my interpersonal and helping } \\
\text { skills in the service of others } \\
\text { - To see other people change because of } \\
\text { my effort } \\
\text { - To enjoy a maximum of freedom and } \\
\text { autonomy to choose my own work, hours, } \\
\text { etc. }\end{array}$ \\
\hline $\begin{array}{l}\text { Pure } \\
\text { Challenge }\end{array}$ & $\begin{array}{l}\text { - To experience an endless variety of } \\
\text { challenges }\end{array}$ \\
\hline
\end{tabular}

\section{Research Questions and Test Hypotheses}

Our objectives in this part of the study are to identify (a) students' perceived differences in the five functional business majors, and (b) the differences between what the students are looking for in their future career and what they believe the IS major would lead them to 
achieve. The testing hypotheses for answering these two questions are:

H1: $\quad \mu_{\mathrm{iIS}}=\mu_{\mathrm{iFin}}=\mu_{\mathrm{iAcc}}=\mu_{\mathrm{iMkt}}=\mu_{\mathrm{iMgt}}$

H2: $\mu_{\mathrm{iVal}}=\mu_{\mathrm{iIS}}$

Whereas:

$\mu_{\mathrm{iIS}}$ is the mean of the $\mathrm{i}^{\text {th }}$ factor (career anchor) of the IS major

$\mu_{\mathrm{iFin}}$ is the mean of the $\mathrm{i}^{\text {th }}$ factor (career anchor) of the finance major

$\mu_{\mathrm{iAcc}}$ is the mean of the $\mathrm{i}^{\text {th }}$ factor (career anchor) of the accounting major

$\mu_{\mathrm{iMkt}}$ is the mean of the $\mathrm{i}^{\text {th }}$ factor (career anchor) of the marketing major

$\mu_{\mathrm{iMgt}}$ is the mean of the $\mathrm{i}^{\text {th }}$ factor (career anchor) of the management major

$\mu_{\mathrm{iVal}}$ is the mean of the $\mathrm{i}^{\text {th }}$ factor (career anchor) of the student's personal preference

\section{Multivariate Analysis of Variance}

Multivariate analysis of variance (MANOVA) is a statistical inference procedure for assessing the statistical significance of differences between groups. The null hypothesis for MANOVA is to test for equality of vectors of means on multiple dependent variables across $\mathrm{k}$ groups. A particular advantage of using MANOVA over a series of univariate ANOVA or $t$ tests is the its power in testing the differences between groups when there is even the presence of multicollinearity among the dependent variables when the combined differences may be hidden for univariate tests.

The dependent variables we tested in MANOVA for both hypotheses are the eight factors representing the career anchor; while the independent variable was the functional major variable. To compare the career outcome differences between the majors, we specified the post hoc contrasts to be conducted using a simple contrasting method. The contrasts were done with the means of the career outcomes factors referencing to those of the IS major.

\section{RESULTS}

Table 2 below summarizes the results of the MANOVA tests comparing the differences between the non-IS majors to IS in terms of the career outcomes factors. The means of the eight factors representing the career anchors of each major are compared to that of those of the IS majors. The two numbers in each cell in Table 2 are the estimated coefficients and the p-values. Only those with a p-value equals 0.05 or smaller are reported.

Table 2 k-contrasts of the MANOVA Results of the Non-IS Majors with Reference to the IS Major

\begin{tabular}{|l|l|c|c|c|}
\hline & \multicolumn{4}{|c|}{ k-Contrast Results with Reference } \\
\hline Career Outcomes & Fin & Acc & Mkt & Mgt \\
\hline Tech. \& Functional & & 0.30 & & \\
(difference \& & & .05 & & \\
p-value) & & & & \\
\hline $\begin{array}{l}\text { Gen. Management } \\
\text { (difference \& }\end{array}$ & & & 0.37 & 1.32 \\
p-value) & & & .016 & .000 \\
\hline Independency \& & & & 0.45 & \\
Life Style & & & .006 & \\
(difference \& & & & & \\
p-value) & & & & 0.50 \\
\hline Security \& Stability & & & & .003 \\
(difference \& & & & & \\
p-value) & & & & \\
\hline Geographic & & & & \\
Security & & & \\
(difference \& & & & & \\
p-value) & & -0.61 & 0.34 & \\
\hline Entrepreneurial & -0.38 & .000 & .032 & \\
Creativity & .015 & & & \\
(difference \& & & & & \\
p-value) & & & 0.58 & 0.92 \\
\hline Service \& Special & & & .000 & .000 \\
Course & & & \\
(difference \& & & & 0.48 & 0.74 \\
p-value) & & & .011 & .000 \\
\hline $\begin{array}{l}\text { Pure Challenge } \\
\text { (difference \& }\end{array}$ & & & & \\
p-value) & & & & \\
\hline
\end{tabular}

A positive coefficient represents a higher likelihood of achieving the respective career outcomes for a given major, compared to IS. While a negative one means an opposite expectation.

Of the four non-IS functional majors, finance is the one most similar to IS in all aspects except for that the students perceived finance to be less likely to provide the career outcome of entrepreneurial creativity than the IS major. Accounting was perceived to be more likely leading to the achievement of technical and functional competency, but less likely to entrepreneurial creativity.

Relatively, marketing and management were perceived to be more different than IS. Students regarded both marketing and management as majors more likely than IS leading to the achievement of competency in general management, servicing other people and a special 
course, and pure challenge. While marketing was thought to be more likely leading to the achievement of independency and maintaining a selected life style, and entrepreneurial creativity; management was perceived to be more likely leading to the achievement of security and stability.

Table 3 below summarizes the results of the MANOVA tests comparing the differences between the IS major and the student subjects' personal preference in terms of the career outcomes factors. The means of the eight factors of the IS major are compared to that of the students' preference and tested for statistical significance. The two numbers in each cell in Table 3 are the estimated coefficients and the p-values. Only those with a p-value equals 0.05 or smaller are reported.

Table 3 Comparison of the MANOVA Results of IS Major and Students' Intrinsic Career Needs

\begin{tabular}{|l|c|}
\hline \multicolumn{1}{|c|}{ Career Outcomes } & $\begin{array}{c}\text { Contrast } \\
\text { IS vs. Indiv }\end{array}$ \\
\hline Tech. \& Functional & \\
(difference \& p-value) & \\
\hline Gen. Management & -0.98 \\
(difference \& p-value) & .000 \\
\hline Independency \& Life Style & -0.95 \\
(difference \& p-value) & .000 \\
\hline Security \& Stability & -0.86 \\
(difference \& p-value) & .000 \\
\hline Geographic Security & -0.83 \\
(difference \& p-value) & .000 \\
\hline Entrepreneurial Creativity & -0.28 \\
(difference \& p-value) & .050 \\
\hline Service \& Special Course & -1.08 \\
(difference \& p-value) & .000 \\
\hline Pure Challenge & \\
(difference \& p-value) & \\
\hline
\end{tabular}

The comparison shows that the IS major was perceived by the students to be unlikely to lead to the achievement of most of the career outcomes at a level compatible to their intrinsic career needs.

\section{CONCLUSION}

In this study, we focused on comparing what outcomes the students regard to be important in their future career paths with those they believe to be attainable by completing the functional business majors. We used Career Anchors to inform us in devising our survey instrument for measuring the outcomes that students seek in their careers. We also examined how students perceive the relationship of these career outcomes to the various majors. In particular, our objectives in this study are to identify (a) students' perceived differences in the five functional business majors in terms of the career anchors, and (b) the differences between what the students are looking for in their future career and what they believe the IS major would lead them to achieve.

Based on the survey data collected from 106 business students, we obtained some preliminary findings which can serve as the first clue in attempting to solve the puzzle as to why these students are failing to see these majors as viable paths that will lead to the outcomes that they are seeking.

The factor structure obtained from the factor analysis performed on students' responses to the questions referencing to the 24-item Career Anchor inventory substantially conforms to the career anchors of Schein and DeLong. In terms of answering our research questions, we found initial evidence that suggests a substantial gap between what the students are looking for in their future career paths and what they perceive to be attainable by choosing IS to be their major of study. The empirical findings also suggest that there are significant perceived differences among the five functional majors in terms of the career outcome factors.

This paper discusses our first effort in seeking to answer the question regarding what motivates students to choose a certain business major. The findings provide useful information that should help business school administrators in reviewing their existing curricula and planning new ones that would better match with the student needs. Moreover, the findings will allow business school administrators to re-focus their public relationship and promotion strategy to make sure that a correct image of the various academic programs is projected to the potential applicants.

\section{REFERENCE}

1. Schein, E.H., (1996) Career anchors revised: Implications for career development in the $21 \mathrm{st}$ century. The Academy of Management Executive. Briarcliff Manor, 10(4): p. 80-88.

2. DeLong, T.J., (1982) Reexamining the Career Anchor Model. Personnel, 59(3): p. 50-61.

3. Unknown, Occupational Outlook Handbook 2006-07 Edition, B.o.L. Statistics, Editor. 2006.

4. George, J.F., Valacich, J.S., and Valor, J., Does information systems still matter? lessons for a maturing discipline, in Paper presented at the 25th International Conference on Informaton Systems. 2004: Washington, DC.

5. Vegso, J., (2007) Continued Drop in CS Bachelor's 
Degree Production and Enrollments as the Number of New Majors Stabilizes. Computing Research News, 19(2).

6. Giacomino, D. and Akcrs, M.D., (1998) An examination of the differences between personal values and value types of female and male accounting and non-accounting majors. Issues in Accounting Education, 13: p. 565-584.

7. Gist, W.E., Goedde, H., and Ward, B.H., (1996) The influence of mathematical skills and other factors on minority student performance in principles of accounting. Issues in Accounting Education, 77: p. 49-57.

8. Staniec, J.F.O., (2004) The effects of race, sex, and expected returns on the choice of college major. Eastern Economic Journal, 30(4): p. 549-562.

9. Malgwi, C., Howe, M., and Burnaby, P., (2005) Influences on students' choice of college major. Journal of Education for Business, 80(5): p. 275-282.

10. Noel, M., Michaels, C., and Levas, M., (2003) The relationship of personality traits and self-monitoring behavior to choice of business major. Journal of Education for Business, 78(3): p. 153.

11. Pritchard, R., Potter, C., and Saccucci, M., (2004) The Selection of a Business Major: Elements Influencing Student Choice and Implications for Outcomes Assessment. Journal of Education for Business, 79(3): p. 152-161.

12. Calkin, L.N. and Welki, A., (2006) Factors that influence choice of major: why some students never consider economics. International Journal of Social Economics. Bradford, 33(8): p. 547.

13. Moody, J., et al., (2003) Diversity and the Information Technology Workforce: Barriers and Opportunities. Journal of Computer Information Systems, 43(2): p. 63-71.

14. Woszczynski, A., Myers, M., and Moody, J., (2006) Student perceptions of diversity issues in IT. Journal of Information Systems Education, 17(4): p. 449-458. 